\title{
The effects of castration and androgen on the social dominance of BALB/cJ male mice*
}

\author{
C. T. LEE and J. N. NARANJO \\ Brooklyn College of the City University of New York, Brooklyn, New York 11210
}

\begin{abstract}
Four experiments were conducted to investigate the relationship between androgen and the maintenance of social dominance in BALB/cJ male mice. Experiment I revealed that 9 out of 10 dominant mice lost their dominant positions after castration, and of the 10 sham-operated dominant mice, 9 still remained dominant. Thus, androgen is necessary for the maintenance of social dominance. Experiment II showed that $.2, .4$, and $.8 \mathrm{mg}$ of testosterone propionate (TP) injected daily to the castrated dominant mice did not restore their precastration dominant positions. Experiment III replicated the second experiment by giving 5 castrated dominant mice $.8 \mathrm{mg}$ of TP and and another $5 \mathrm{mice} 1.2 \mathrm{mg}$ of TP. Neither treatment restored the precastration dominant status of the treated mice. The animals were then injected with $4 \mathrm{mg}$ of TP, which was not effective in restoring their precastration dominance position. The $8 \mathrm{mg}$ of TP used in Experiment IV was also not effective. The relationship between androgen and social order was discussed.
\end{abstract}

Social animals generally form definite social structures which promote group survival (Wynne-Edwards, 1962). One of the most investigated social structures is the dominance-subordination hierarchy. This social hierarchy is maintained by intricate networks of agonistic interactions among the members of the social group. The dominant animal has frequently been observed to have better access to food, water, mates, and territory than the submissive animals (Collias, 1944). Among all the advantages, the reproductive advantage of the dominant animal is probably the most significant one. Field observations have revealed that the dominant elephant seals, $4 \%$ of the male population, inseminate approximately $85 \%$ of the females (LeBoeuf \& Peterson, 1969); and the dominant sage grouse perform approximately $80 \%$ of the total mating frequency during the breeding sessions (Scott, 1942). DeFries and McClearn (1970), in investigating the relationship between social dominance and Darwinian fitness as measured by the relative number of litters sired, have observed that the dominant mouse sired approximately $92 \%$ of the progeny in group-housed mice. These mating systems clearly deviate from random mating, and consequently may result in the alteration of gene frequency in the gene pool (Falconer, 1960). Therefore, it is of importance to investigate factors affecting the social dominance.

The present study was designed primarily to investigate the effect of androgen on social dominance in Mus musculus, which has been the most frequently studied animal for the investigation of hormonal effects

\footnotetext{
*This research was supported by (a) Grant GU-1598 from National Science Foundation (University Science Development Program), while C.T.L. was a Faculty Associate at the University of Texas at Austin, (b) Faculty Research Award 1467 from the City University of New York, awarded to C.T.L., and (c) an Undergraduate Excellence Research Grant from the University of Texas at Austin, awarded to J.N.N. A portion of this research was presented at the AAAS meeting, 1972.
}

on aggressive behavior (Bronson \& Desjardins, 1971). Androgen has been reported to be a necessary condition for the development of aggressive behavior (Levy \& King, 1953), to exert possible organizing effects on the central neural sites for responding differentially to endogenous hormones (Edwards, 1968, 1969; Bronson \& Desjardins, 1968, 1969), and to affect the production of aggression urinary pheromone (Lee \& Brake, 1972; Lee \& Griffo, 1973; Mugford \& Nowell, 1970). However, the relationship between androgen and the dominance-subordination hierarchy is not very clear, for there is no available report systematically investigating the role of hormones in maintaining the social dominance of the house mouse. The present series of studies attempted to find answers to two questions: (a) Is androgen necessary for maintaining social dominance? (b) Is hormonal therapy effective in restoring dominance position? Groups of four male BALB/cJ inbred mice were allowed to establish a definite social hierarchy. The dominant mouse was then castrated and later given TP injections. The effects of castration and hormone therapy on social dominance were evaluated.

\section{EXPERIMENT I}

Experiment I was conducted to investigate the effect of castration on the social status of the dominant mouse.

\section{Method}

\section{Subjects}

Eighty BALB/cJ male mice were purchased from Roscoe B. Jackson Memorial Laboratory at 6 weeks of age. Upon arrival, they were housed singly in polypropylene cages and maintained under a reversed day-night cycle $(12: 12 \mathrm{~h})$. Water and Wayne-Blox were given ad lib. Testing commenced at 9 weeks of age, and the mice were randomly assigned to 1 of 20 groups of four mice per quadrangular unit. Before being placed in the unit, each mouse was randomly assigned to Cage A, B, C, or D. The 
Table 1

Experimental Schedule for Experiment I

Phase 1

Adaptation

Social Interaction (1)

Dominance Test (1)

2 Days

7 Days

1 Day

Phase 2

$\begin{array}{lc}\begin{array}{lc}\text { Isolation Period } \\ \text { Operation }\end{array} & 2 \text { Days } \\ & 1 \text { Day } \\ \text { Social Interaction (2) } & 3 \text { Days } \\ \text { 3rd-Day Dominance Test } & 12 \mathrm{H} \\ \text { Social Interaction (3) } & 4 \text { Days } \\ \text { 7th-Day Dominance Test } & 12 \mathrm{H} \\ \text { 9th-Day Dominance Test } & 2 \text { Days }\end{array}$

Ss randomly assigned to 20 quadrangular units and allowed 2 days for adaptation to their assigned cage.

Ss observed twice daily for $10 \mathrm{~min}$ each period. Data recorded: movement, fights won and lost, dominant mouse and submissive mice.

$24 \mathrm{~h}$ of isolation followed by a 1-min dominance test per $\mathrm{S}$ in the dominant mouse's cage.

\section{Ss isolated in their own cage.}

Half of the dominant mice were randomly selected and castrated. The remaining dominant mice were sham operated.

Same as Social Interaction (1).

Same as Dominance Test (1) except conducted in the present dominant mouse's cage.

Same as Social Interaction (1)

Same as 3rd-Day Dominance Test.

After 2 days of isolation, dominance tests were conducted in the castrated dominant mice cages. This was followed by a post mortum scrotum examination. tails of the mice assigned to the four cages were dyed blue, red, green, or plain (in that order) for identication purposes.

\section{Apparatus}

The dominance-subordination hierarchy was observed in quadrangular units composed of four $7 \frac{1}{2} \times 11 \times 5 \frac{1}{2}$ in. polypropylene cages, which were connected by four $2 \times 7$ in. Plexiglas tubes. Stopwatches and hand counters were utilized in collecting data. Light on the ceiling provided illumination for observations. Animals were observed during the dark phase of the day-night cycle.

\section{Procedure}

Table 1 summarizes the experimental schedule, which consisted of two phases. In Phase 1 , the mice were allowed to establish a dominance order, and in Phase 2, the dominant mice were either castrated or sham operated. Phase 1 began with a 2-day adaptation period to the cages, after which the segregation tabs at each end of the tubes connecting the cages were removed and the mice were allowed to move freely within the quadrangular unit. During the social interaction period, interactions of the mice in each unit were observed twice daily for a period of $10 \mathrm{~min}$ per session until a dominant mouse emerged in each unit. The initial location of the mice, their movement, fights won or lost, and mutual fights (fighting situation in which there is no apparent winner) were recorded for each unit. Tabs were then inserted into the tubes, and the mice were isolated in their initial cages for $24 \mathrm{~h}$. The dominant mouse was easily identifiable behaviorally. It had free access to food and cages, frequently attacked other mice, and never crouched in a corner with other mice. However, to confirm the observed dominance order, a dominance test lasting 1 min per mouse was conducted in the dominant mouse's cage at the end of the isolation period. The dominance test consisted of placing a mouse in the dominant mouse's cage. The latency of the dominant mouse's first attack and the number of attacks were recorded.

At the beginning of Phase 2, the mice were isolated for 2 days. The 20 dominant mice were randomly assigned to two groups. Group 1 received sham operations and Group 2 received a bilateral gonadectomy. The operation was followed by 1 day of isolation, after which the animals were allowed to interact for 3 days or until a social order was established. On the third day of observation after the operations, the mice were isolated in their initial cages for $12 \mathrm{~h}$. A dominance test was conducted in the present dominant mouse's cage, and the appropriate data were recorded. The mice were then allowed to interact for 4 more days, and another dominance test was conducted. The mice then remained isolated in their initial cages for 2 days, after which a final dominance test was carried out in the castrated dominant animal's cage to confirm the social status of the castrates. The experiment was concluded with a post mortum investigation of the gonads of the mice to confirm that the castration was successful and that the sham operations did not cause any anatomical damage.

\section{Results}

When the quadrangular units were first opened, mutual fights were observed. By the second day of observation, a dominant mouse, identified by both behavioral observation and the colored-tail system, had emerged in each unit. The dominant mouse attacked and chased the other mice. By the third day of observation, the dominant mouse restricted the movement of the three submissive mice to such an extent that they mainly stayed huddled together in the corner of one cage. The dominant mice frequently attacked and bluffed the submissive mice, even though the submissive mice assumed submissive postures.

On the day prior to sham operation and castration, the dominance order was stable, as indicated by the results obtained in the 10-min observation period, which was supported by the data of the dominance tests (see Table 2). Three days after castration, 9 dominant mice lost their dominant positions $(p<.05)$. Of the 10 sham-operated mice, 9 still remained dominant $(p<.05)$. The mean number of attacks received by the dominant mice in the dominance test before and after sham operation rose only slightly from 0 to .6. The mean number of attacks received by the castrated dominant mice before and after castration changed significantly 
from 0 at initial testing to 4.3 by the third day and 3.9 on the seventh day after castration $(p<.05)$. The mean number of attacks received by the new dominant mice fell significantly $(p<.05)$. During the initial dominance test, the mean number of attacks received was 13.2, as compared to the third-day dominance test, in which the mean number of attacks received was .7 , and to the seventh day dominance test, in which the mean number of attacks received was .4. A similar pattern of changes was also observed in the latency of the first attack.

The dominance test conducted on the ninth day after castration in the castrated dominant mouse's cage indicated that the cage owner showed avoidance behavior rather than aggressive behavior toward the tested mouse.

\section{EXPERIMENT II}

The results of Experiment I clearly demonstrate that castration of the dominant mice produced a reversal in the dominance hierarchy. Experiments II, III, and IV were designed to investigate the effects of hormone therapy on the social status of the dominant mouse. The mice used and the procedure employed in the three experiments were similar to those of Experiment I with some modification in the experimental design.

\section{Method}

\section{Subjects}

Sixty BALB/cJ male mice, purchased at 6 weeks of age, were randomly assigned to 15 quadrangular units at 9 weeks of age.

\section{Procedure}

The procedure in Experiment II consisted of four phases, as
Table 2

Mean Attacks Received by the Dominant Mice Before and After Castration or Sham Operation

\begin{tabular}{|c|c|c|c|c|}
\hline $\begin{array}{c}\text { Before } \\
\text { Opera- } \\
\text { tion (A) }\end{array}$ & $\begin{array}{c}\text { 3rd Day } \\
\text { After } \\
\text { Opera- } \\
\text { tion (B) }\end{array}$ & $\begin{array}{l}7 \text { th Day } \\
\text { After } \\
\text { Opera- } \\
\text { tion (C) }\end{array}$ & \multicolumn{2}{|c|}{ Sign Test* } \\
\hline \multicolumn{5}{|c|}{ Castrated Dominant Ss } \\
\hline 0 & 4.3 & 3.9 & $\begin{array}{l}\text { A vs B } \\
\text { A vs C } \\
B \text { vs C }\end{array}$ & $\begin{array}{l}\mathrm{p}<.05 \\
\mathrm{p}<.05 \\
\text { n.s. } \dagger\end{array}$ \\
\hline \multicolumn{5}{|c|}{ New Dominant Ss } \\
\hline 13.2 & .7 & .4 & $\begin{array}{l}A \text { vs } B \\
A \text { vs C } \\
B \text { vs C }\end{array}$ & $\begin{array}{l}\mathrm{p}<.05 \\
\mathrm{p}<.05 \\
\text { n.s. }\end{array}$ \\
\hline \multicolumn{5}{|c|}{ Sham-Operated Dominant Ss } \\
\hline 0 & 0 & .6 & $\begin{array}{l}A \text { vs } B \\
A \text { vs C } \\
B \text { vs C }\end{array}$ & $\begin{array}{l}\text { n.s. } \\
\text { n.s. } \\
\text { n.s. }\end{array}$ \\
\hline
\end{tabular}

*Sign test (Siegel, 1956)

†Not significant

indicated in Table 3. Phase 1 and Phase 2 were similar to Experiment I, with the exception that all the dominant mice were castrated at the beginning of Phase 2 and the remaining mice were sham-operated. In Phase 3 , mice remained isolated in their initial cages for 7 days. During this period, eight castrated dominant mice were randomly selected and injected daily with $.2 \mathrm{mg} / .02 \mathrm{cc}$ TP and the remaining seven castrated dominant mice received daily injections of $.4 \mathrm{mg} / .02 \mathrm{cc}$ TP. The remaining mice received daily injections of $.02 \mathrm{cc}$ oil. After the seventh day of injection, the mice were allowed to interact freely for 3 days. The injections continued during the 3 days of observation. After the third day of observation, the mice were returned to their initial cages for $12 \mathrm{~h}$ and a dominance test was conducted. At the end of Phase 3, the mice were isolated in their own cages for 2 weeks. Phase 4 was a replication of Phase 3, except that all 15 castrated mice received injections of $.8 \mathrm{mg} / .02 \mathrm{cc}$ of TP. TP was purchased from Sigma Chemical Company and was dissolved in pure corn oil.

Table 3

Experimental Schedule for Experiment II

\begin{tabular}{|c|c|c|}
\hline \multicolumn{3}{|l|}{ Phase 1} \\
\hline Adaptation & 2 Days & Same as Experiment I. \\
\hline Social Interaction (1) & 3 Days & Same as Experiment I. \\
\hline Dominance Test (1) & $12 \mathrm{H}$ & Same as Experiment I. \\
\hline \multicolumn{3}{|l|}{ Phase 2} \\
\hline Operation & 1 Day & $\begin{array}{l}\text { All the dominant mice were castrated and the remaining mice received sham opera- } \\
\text { tion. }\end{array}$ \\
\hline Social Interaction (2) & 4 Days & Same as Social Interaction (1). \\
\hline Dominance Test (2) & $12 \mathrm{H}$ & Same as Dominance Test (1) \\
\hline \multicolumn{3}{|l|}{ Phase 3} \\
\hline Injection Period & 7 Days & $\begin{array}{l}\text { Ss were isolated in their initial cages. Eight dominant mice were injected with } .2 \mathrm{mg} / \\
.02 \mathrm{cc} \text { TP daily, and seven dominant mice received } .4 \mathrm{mg} / .02 \mathrm{cc} \text { TP injection. The } \\
\text { remaining mice received placebo injections. }\end{array}$ \\
\hline Social Interaction (3) & 3 Days & Ss received injections daily and were observed as Social Interaction (1). \\
\hline Dominance Test (3) & $12 \mathrm{H}$ & Same as Dominance Test (1). \\
\hline \multicolumn{3}{|l|}{ Phase 4} \\
\hline Isolation Period & 14 Days & Ss isolated for 14 days to dispel effects of injections. \\
\hline Injection Period & 7 Days & $\begin{array}{l}\text { Castrated dominant mice received daily injection of } .8 \mathrm{mg} / .02 \mathrm{cc} \mathrm{TP} \text {. The remaining } \\
\text { mice received placebo injections. }\end{array}$ \\
\hline Social Interaction (4) & 3 Days & Ss received daily injections and were observed as Social Interaction (1). \\
\hline Dominance Test (4) & $12 \mathrm{H}$ & Same as Dominance Test (1). \\
\hline
\end{tabular}




\section{Results}

The results of Phases 1 and 2 of the experiment were similar to those of Experiment I. A dominance order was observed in all 15 units at the end of Phase 1. In Phase 2, after the castration of the dominant mice, all units showed a reversal of the dominance hierarchy $(p<.01)$. In Phase 3, the .2- and .4-mg injections of TP did not restore the treated mice to a position of dominance. The Phase 2 hierarchy was reestablished shortly after the initial fighting period. The .8-mg injections of TP also did not restore the dominance status of the treated mice. Four of the treated mice, however, showed increased amounts of aggression, which subsided within $48 \mathrm{~h}$.

\section{EXPERIMENT III}

Although the .2-, .4-, and .8-mg injections of TP did not restore the castrated-dominant animals' dominant position, the .8-mg injections of TP did increase the aggressiveness of four treated mice. The results suggested that dosages higher than $.8 \mathrm{mg}$ might be needed to restore the dominance of the castrated dominant mice. Thus, doses of .8 and $1.2 \mathrm{mg}$ of TP were used in this experiment.

\section{Method}

\section{Subjects, Apparatus, and Procedure}

Forty naive BALB/cJ male mice were randomly assigned to 10 quadrangular units. The experimental schedule consisted of a four-phase process. Phases 1 and 2 were similar to Experiment II, except that both social interaction periods lasted 4 days. During Phase 3 , half of the castrated dominant mice were injected daily with $.8 \mathrm{mg} / .02 \mathrm{cc}$ of TP; and the other half were injected daily with $1.2 \mathrm{mg} / .02 \mathrm{cc}$ of TP. The remaining mice received placebo injections throughout the 14-day injection period. A social interaction period and a dominance test were conducted, as in Experiment II. Phase 4 was similar to Experiment II except that two daily injections of $2 \mathrm{mg} / .1 \mathrm{cc}$ of TP were administered to four of the remaining castrated mice.

\section{Results}

The results of Phases 1 and 2 were similar to those of Experiment II. A stable dominance-subordination hierarchy was observed after 4 days of free social interaction. After 4 days of castration, a new dominant mouse had emerged in every quadrangular unit $(p<.01)$. By the third phase, two castrated mice had died. The injections resulted in pseudodominance for one castrated mouse from the $.8-\mathrm{mg}$ group and one castrated mouse from the 1.2-mg group. These two mice were dominant for only 2 days. Using four quadrangular units for the injection of $4 \mathrm{mg}$ of TP in Phase 4, mutual fighting and initiation of attacks was observed in all units; however, by Day 2, there were only two castrates in control of their units, as indicated by the number of attacks exhibited by these mice. By Day 4, all of the castrates were again submissive.

\section{EXPERIMENT IV}

After reviewing the results of Experiments II and III and noting the progressive increase in aggressiveness of the castrated dominant mice, Experiment IV was conducted to determine if daily injections of $8 \mathrm{mg}$ of TP would allow the castrated mice to regain their dominant position in their social hierarchies.

\section{Method}

\section{Subjects, Apparatus, and Procedure}

Forty naive BALB/cJ male mice were assigned to 10 quadrangular units. The experimental schedule consisted of three phases. Phases 1 and 2 were similar to those of Experiment II. During Phase 3 , the castrated dominant mice received injections of $8 \mathrm{mg} / .1 \mathrm{cc}$ of $\mathrm{TP}$, and the remaining mice received oil injections. The mice were then allowed to interact for 5 days.

\section{Results}

The results of Phases 1 and 2 were similar to those of the previous experiments. A definite dominance hierarchy was observed in every unit by the end of Phase 1, and a reversal of the dominance position occurred by the end of Phase $2(p<.01)$. In Phase 3 , the injections of $8 \mathrm{mg}$ of $\mathrm{TP}$ to the castrates did not permanently restore their social status. On the first day of observation, all hormone-treated animals exhibited mutual fights, with a mean of 30.0. However, by the second day of observation, 6 of the 10 castrated mice exhibited mutual fights with other animals in their units, and 3 of the 6 animals exhibited attacks to other mice in their own units. Nevertheless, by the third day, only 1 hormone-treated castrated mouse was dominant, and on the fourth and fifth days, all of the hormone-treated castrated mice were submissive.

\section{DISCUSSION}

The objective of the present series of experiments is to investigate the role of androgen in maintaining the social dominance. The results indicate that (a) deprivation of endogenous androgen by castration readily reverses the social status of the dominant mice, and (b) exogenous androgen therapy, though enhancing the aggressive behavior of the castrated dominant mice, does not restore the social status.

In the discussion of the internal causes of agonistic behavior, Scott (1958) has concluded that "the male hormone must be present in order to get the animal to start fighting but is not necessary once a strong habit has been established." The statement is derived from the observation that mice with fighting experience continued to exhibit aggressive behavior after castration (Beeman, 1947a; Bevan et al, 1960). Beeman (1947a) noted that experienced fighters remained aggressive after castration. In view of these observations, the readiness of the dominance reversal observed in the present series of 
experiments is rather surprising. The castrated dominant mice were engaged in fighting after castration; however, inevitably their aggressive behavior and dominance subsided over a period of approximately 4 days. Thus, it is possible that endogenous androgen may play an important role in maintaining the vigor or persistency of fighting which is necessary for maintaining dominance in the social hierarchy of mice. The reversal of dominance was also observed in Japanese quails (Selinger \& Bermant, 1967) which were tested in a paired competition situation. However, Green et al (1972) reported that castration of the dominant squirrel monkeys did not result in alteration of the social order in group-housed monkeys. Likewise, androgen injections to the castrated dominant monkey and the female did not change significantly the frequency of dominance displays and feeding dominance orders.

The results of the hormonal therapy may be considered to support the hypothesis that androgen maintains the vigor or persistency of fighting necessary for maintaining the social hierarchy. As the dosage of TP increased, there was also an increased number of hormone-treated mice exhibiting a greater number of mutual fights, and a tendency to restore their social dominance, though none of the dosages used were effective in restoring permanently the-preoperation status. Two explanations may account for the failure of the hormonal therapy. First, it is possible that a continuous flow of endogenous androgen rather than an acute injection of androgen is required to maintain the vigor of aggressive behavior and thus the social dominance. This hypothesis may be tested by implanting the hormone to the castrated mice immediately after operation. Beeman (1947b) showed that implantation of androgen (approximately $15 \mathrm{mg}$ of $\mathrm{TP}$ ) restored the aggressiveness of castrated mice. However, data on the maintenance of social dominance with androgen implantation is still lacking. Secondly, it is possible that once the animal has experienced a dominant role and is then suddenly deprived of it, the animal might not be able to regain its supremacy, in spite of the fact that it will have received hormone treatment. Two observations of Ginsburg and Allee (1942) tend to support this view. They found that (a) after being subjected to a series of defeats by a superior fighter, an intact dominant mouse inevitably developed a generalized submissive and avoidance behavior toward mice of its own social group, and (b) it was very difficult to condition the submissive mouse to become aggressive. Since the castrated dominant mice in the present study became submissive after operation, the failure of hormonal therapy to restore precastration dominance may then be expected. Results of Work et al (1969) and Lumia (1972) tend to support the second explanation. Work et al (1969) studied the social dominance of six castrated rats. The social hierarchy was constructed by observing the outcome of all possible pair competition in a food-seeking situation. Injection of testosterone to selected rats did not change the initial hierarchy. However, if the number of wins and losses of the animals are equalized by pairing the rats with confederates, testosterone treatment then advances the social position of the treated rat. Lumic (1972) investigated the effects of androgen and the experience of attacking dominant birds on social dominance in group-housed pigeons. Results indicated that the treatment of androgen to low-ranking birds and the allowance of these birds to attack the dominant birds in a separate situation are the most effective methods to advance the social status of the treated birds. Hormonal therapy given alone to the low-ranking birds does not produce significant changes in the social status of these birds.

The effect of androgen on the social status reported by various researchers appears to be inconsistent possibly because of (a) species differences in responding to hormone treatment and (b) the lack of taking experiential factors into consideration. Mirsky (1955) has observed the social dominance of two social groups of gonadectomized macaque monkeys, five males in one group and five females in the other, and found that in no case did implantation of gonadal hormones (androgen or estrogen) improve the social status of low-ranking animals. A similar treatment did not affect the dominance order in a paired competition situation either. Davis (1957) has also reported a failure of TP administration in changing the social rank of treated starlings in a social group consisting of all male castrated starlings. But Mathewson (1961) has reported that leuteinizing hormone administration improves social status of starlings in a paired competition situation. Crook and Butterfield (1968) made a similar observation in weaver birds, namely androgen is ineffective but leuteinizing hormone is effective in altering social dominance. On the contrary, Allee et al (1939), Bennett (1940), and Noble and Borne (1940) have reported a success of social status changes after TP administration to members of group-housed female chickens, male and female ringdoves, and female swordtail fish, respectively. And Clark and Birch (1945) have found that testosterone was effective in advancing the social dominance in a paired competition situation of male castrated chimpanzee. In addition, Selinger and Bermant (1967) have reported that androgen therapy to castrated Japanese quail effectively restores the precastration dominance of the treated birds. The effectiveness of androgen in changing social hierarchy appears to be also affected by the experience of the animals, as indicated by studies of Work et al (1969) and Lumia (1972).

Two other interesting observations emerged from these four experiments. First, the established dominance relationship during Phase 1 of all experiments was, without any variation, an exclusive dominance order, which is described by Uhrich (1938) as dominance by one male of the group without observed resistance from any of the other members. Secondly, the observation that there was a decrease in the frequency of fighting 
and that the movement of submissive mice was restricted by the dominant mouse was also in congruence with Uhrich's (1938) results.

\section{REFERENCES}

Allee, W. C., Collias, N. E., \& Lutherman, C. Z. Modification of the social order in flocks of hens by the injection of testosterone propionate. Physiological Zoology, 1939, 12, $412-440$.

Beeman, E. A. The relation of the interval between castration and first encounter to the aggressive behavior of mice. Anatomical Record, 1947a, 99, 570-571.

Beeman, E. A. The effect of male hormone on aggressive behavior in mice. Physiological Zoology, 1947b, 20, 373-405.

Bennett, M. A. The social hierarchy in ring doves. II. The effect of treatment with testosterone propionate. Ecology, 1940, 21, 148-165.

Bevan, W., Daves, W. F., \& Levy, G. W. The relation of castration, androgen therapy and pre-test fighting experience to competitive aggression in male $\mathrm{C} 57 \mathrm{BL} / 10$ mice. Animal Behaviour, 1960, 8, 6-12.

Bronson, F. H., \& Desjardins, C. Aggression in adult mice: Modification by neonatal injections of gonadal hormones. Science, 1968, 161, 705-706.

Bronson, F. H., \& Desjardins, C. Aggressive behavior and seminal vesicle function in mice: Differential sensitivity to androgen given neonatally. Endocrinology, 1969, 85, 971-974.

Bronson, F. H., \& Desjardins, C. Hormones and aggression. In B. E. Eleftheriou and J. P. Scott, The physiology of aggression and defeat. New York: Plenum Press. Pp. 43-63.

Clark, G., \& Birch, H. G. Hormonal modification of social behavior. I. The effect of sex hormone administration on the social status of a male castrate chimpanzee. Psychosomatic Medicine, 1945, 7, 321-329.

Collias, N. E. Aggressive behavior among vertebrate animals. Physiological Zoology, 1944, 17, 83-123.

Crook, J. H., \& Butterfield, P. A. Effects of testosterone propionate and leuteinizing hormone on agonistic and nest building behavior of Quelea quela. Animal Behaviour, 1968, $16,370-384$

Davis, D. E. Aggressive behavior in castrated starlings. Science, 1957, 126, 253.

DeFries, J. C., \& McClearn, G. E. Social dominance and Darwinian fitness in the laboratory mouse. American Naturalist, 1970, 104, 408-411.

Edwards, D. A. Mice: Fighting by neonatally androgenized females. Science, 1968, 161, 1027-1028.

Edwards, D. A. Early androgen stimulation and aggressive behavior in male and female mice. Physiology \& Behavior, 1969, 4, 333-338.

Falconer, D. S. Introduction to quantitative genetics. Edinburgh: Oliver \& Boyd, 1960.
Ginsburg, B., \& Allee, W. C. Some effects of conditioning on social dominance and subordination in inbred strains of mice. Physiological Zoology, 1942, 15, 485-506.

Green, R., Whalen, R. E., Rutley, B., \& Battie, C. Dominance hierarchy in squirrel monkeys (Saimiri sciureus). Folia Primatus, 1972, 18, 181-195.

LeBoeuf, B. J., \& Peterson, R. S. Social status and mating activity in elephant seals. Science, 1969, 163, 91-93.

Lee, C. T., \& Brake, S. C. Reaction of male mouse fighters to male castrates treated with testosterone propionate or oil. Psychonomic Science, 1972, 27, 287-288.

Lee, C. T., \& Griffo, W. Early androgenization and aggression pheromone in inbred mice. Hormones \& Behavior, 1973, 4, 181-189.

Levy, J. V., \& King, J. A. The effect of testosterone propionate on fighting behavior in young male C57BL/10 mice. Anatomical Record, 1953, 117, 562-563.

Lumia, A. R. The relationships among testosterone, conditioned aggression, and dominance in male pigeons. Hormones \& Behavior, 1972, 3, 277-286.

Mathewson, S. G. Gonadotrophic hormones affect aggressive behavior in starlings. Science, 1961, 134, 1522-1523.

Mirsky, A. F. The influence of sex hormones on social behavior in monkeys. Journal of Comparative \& Physiological Psychology, 1955, 48, 327-335.

Mugford, R. A., \& Nowell, N. W. Pheromones and their effect on aggression in mice. Nature (London), 1970, 266, 967-968.

Noble, G. K., \& Borne, R. The effect of sex hormones on the social hierarchy of Xiphorus helleri. Anatomical Record, 1940, 78, Supplement 147 (Abstract).

Scott, J. P. Animal behavior. Chicago: University of Chicago Press, 1958. P. 73.

Scott, J. W. Mating behavior of the sage grouse. Auk, 1942, 59, 477498 .

Selinger, H. E., \& Bermant, G. Hormonal control of aggressive behavior in Japanese quail (Coturnix c. japonica). Behaviour, 1967, 28, 255-268.

Siegel, S. Nonparametric statistics for the behavioral sciences. New York: McGraw-Hill, 1956.

Uhrich, J. The social hierarchy in albino mice. Journal of Comparative Psychology, 1938, 25, 373-413.

Work, M. S., Grossen, N., \& Rogers, H. Role of habit and androgen level in food-seeking dominance among rats. Journal of Comparative \& Physiological Psychology, 1969, 69, 601-607.

Wynne-Edwards, V. S. Animal dispersion in relation to social behavior. New York: Hafner, 1962.

(Received for publication August 20, 1973; revision received October 25,1973 .) 